\title{
Zdolności organizacyjne przedsiębiorstwa - ujęcie procesowe
}

\author{
Dr hab. Marek Brzeziński, prof. WSEl iD \\ Wyższa Szkoła Ekonomii i Innowacji w Lublinie \\ Wydział Administracji i Nauk Społecznych \\ Zakład Zarządzania i Innowacji
}

\section{Wprowadzenie}

Zdolność przedsiębiorstwa do rekonfiguracji zasobów i kompetencji w nowe i rozwojowe poziomy zdolności operacyjnej i zdolności dynamicznej, jako komplementarnych składowych dynamicznych zdolności organizacyjnych przedsiębiorstwa, tworzy możliwości kształtowania jego potencjału. Kompleksowe podejście do nurtów operacyjnego i strategicznego w kontekście dynamiki przedsiębiorstwa uwzględnia zasoby i kompetencje kształtowane na bazie procesów organizacyjnych jako kluczowych czynników dynamiki przedsiębiorstwa. Wielowymiarowość kategorii opisujących funkcjonowanie przedsiębiorstwa w czasie wymaga również nowego spojrzenia na problemy jego dynamiki oraz poszukiwania modelu rozwoju zdolności organizacyjnych przedsiębiorstwa.

Zmiany uwarunkowań dynamiki otoczenia z powodu złożoności, zmienności i nieprzewidywalności, szczególnie w dłuższym horyzoncie czasowym, powodują problemy wiązania działalności operacyjnej i strategicznej przedsiębiorstwa. Strategiczne założenia ukierunkowują rozwój przedsiębiorstwa, stając się poszukiwaniem potencjału w postaci zdolności dynamicznych (strategicznych). Jednocześnie pojawiają się problemy związane z codziennym funkcjonowaniem - w postaci zdolności operacyjnych przedsiębiorstwa. Poziomy obu rodzajów zdolności organizacyjnych ${ }^{1}$ powinny stanowić komplementarną całość, równoważącą te aktywności w funkcjonowaniu nowoczesnych przedsiębiorstw.

1 K. Krzakiewicz, S. Cyfert, The Strategic Dimension of the Dynamic Capabilities Enterprises, „Management” 2014, vol. 18, no. 2, s. 7-18; K. Krzakiewicz, S. Cyfert (red.), Strategiczny wymiar dynamicznych zdolności polskich przedsiębiorstw, Wydawnictwo Uniwersytetu Ekonomicznego w Poznaniu, Poznań 2017; A. Wójcik-Karpacz, Zdolności dynamiczne versus zdolności operacyjne, „Organizacja i Kierowanie” 2017, nr 1, s. 51-70; A. Wójcik-Karpacz, Zdolności 
Celem opracowania jest prezentacja koncepcji procesowego ujęcia zdolności organizacyjnych przedsiębiorstwa i ich rozwoju w postaci modelu funkcji logistycznej. Procesualny charakter podejścia zapewnia opis zmian zdolności organizacyjnych w czasie procesu narastania tych zdolności w przedsiębiorstwie. Rozdział ma charakter teoretyczny, wykorzystano w nim wnioskowanie dedukcyjne i metody refleksji naukowej oraz syntetyzowanie wiedzy na temat zdolności organizacyjnych.

\section{Charakterystyka zdolności organizacyjnych}

Zasobowa teoria przedsiębiorstwa, zwana również podejściem zasobowym, od wielu lat ma znaczące miejsce w strategicznym zarządzaniu przedsiębiorstwem ${ }^{2}$. Z tej perspektywy przedsiębiorstwo buduje przewagę konkurencyjną poprzez konfigurowanie i integrowanie zasobów i kompetencji w efektywnie realizowanych procesach organizacyjnych. W krajowych przedsiębiorstwach poziom tworzenia i wykorzystywania zasobów i kompetencji jest trudno porównywalny - według przyjętych kryteriów badawczych i analitycznych w ramach potencjału tych przedsiębiorstw ${ }^{3}$.

W podejściu zasobowym następuje merytoryczne przesuwanie środka ciężkości w stronę zdolności organizacyjnych ${ }^{4}$, uwypuklające ich rolę i znaczenie w tworzeniu potencjału nowoczesnych przedsiębiorstw. Zdolności organizacyjne rozumiane są jako pakiet uzdolnień, umiejętności i technologii przedsiębiorstwa, wyróżniający lepszy sposób wdrażania, alokowania i koordynowania zasobów, trudny do naśladowania i zapewniający przewagę na rynku ${ }^{5}$.

organizacyjne w kontekście wyników przedsiębiorstwa. Aspekty teoretyczne i wyniki badań empirycznych, Wydawnictwo Naukowe PWN, Warszawa 2019.

2 J.B. Barney, D.N. Clark, Resource-based theory. Creating and sustaining competitive advantage, Oxford University Press, New York 2007; R. Krupski, Rozwój szkoły zasobowej zarzq̨dzania strategicznego, Wydawnictwo Wyższej Szkoły Zarządzania i Przedsiębiorczości, Wałbrzych 2011; C. Suszyński, Szkoła zasobowa wobec przeobrażeń otoczenia współczesnych przedsiębiorstw, Wydawnictwo Wyższej Szkoły Zarządzania i Przedsiębiorczości, Wałbrzych 2011.

3 A. Sopińska, Potencjał zasobowy polskich przedsiębiorstw, [w:] M. Romanowska, W. Mierzejewska (red.), Przedsiębiorstwo odporne na kryzys, Wolters Kluwer, Warszawa 2016; A. Wójcik-Karpacz, Zdolności organizacyjne...; A. Zakrzewska-Bielawska, Strategie rozwoju przedsiębiorstw. Nowe spojrzenie, Polskie Wydawnictwo Ekonomiczne, Warszawa 2018.

4 K.M. Eisenhardt, J.A. Martin, Dynamic capabilities: What are they?, „Strategic Management Journal” 2000, vol. 21, s. 1105-1121; M.A. Peteraf, J.B. Barney, Unraveling the resource-based tangle, „Managerial and Decision Economics” 2003, vol. 24(4), s. 309-323.

5 S.J. Wu, S.A. Melnyk, B.B. Flynn, Operational capabilities: The secret ingredient, „Decision Sciences" 2010, vol. 41(4), s. 72-754. 
W ramach zdolności organizacyjnych przedsiębiorstwa wyróżnia się:

- zdolności operacyjne - zdolności „niższego rzędu” (np. rutynowe czynności, administracja i podstawowe zarządzanie), które mają charakter operacyjny i pozwalają realizować dany program produkcyjny lub zestaw działań mniej lub bardziej skutecznie ${ }^{6}$;

- zdolności dynamiczne - zdolności przedsiębiorstwa do tworzenia, integrowania i rekonfigurowania wewnętrznych i zewnętrznych zasobów/kompetencji, skierowanych na adaptację do szybko zmieniających się warunków otoczenia biznesowego lub kształtowania tych zmian?.

Zdolności operacyjne (nazywane także zwykłymi) są zintegrowaną konfiguracją zasobów i kompetencji operacyjnych powiązanych z rutynami operacyjnymi jako wzorcami działań w procesach organizacyjnych przedsiębiorstwa (rysunek 1), natomiast zdolności dynamiczne (nazywane strategicznymi, wyższego rzędu) są już zdolnościami tworzącymi nowe możliwości na wyższym poziomie i wykorzystującymi w nowy sposób zasoby, kompetencje i rutyny operacyjne jako „przeniesione” składowe zdolności dynamicznych przedsiębiorstwa, uwzględniające zmienność otoczenia.

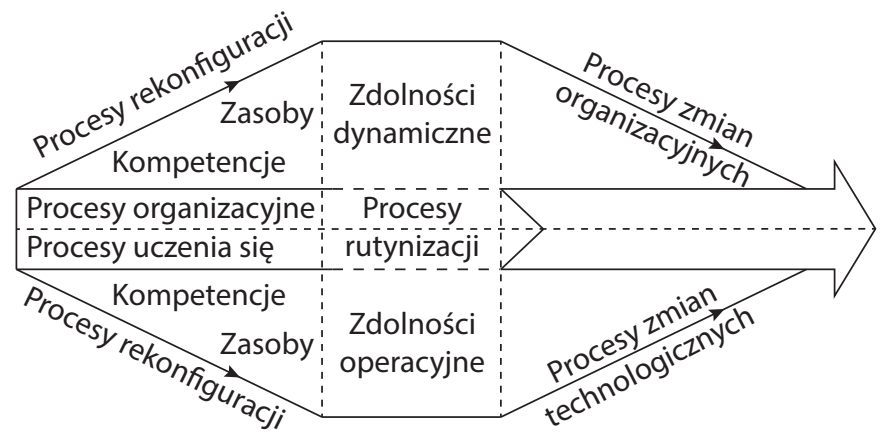

Rysunek 1. Mapa procesów kształtujących zdolności organizacyjne Źródto: opracowanie własne.

Oba rodzaje zdolności organizacyjnych składają się z rutyn organizacyjnych, które współtworzą dwa poziomy zdolności organizacyjnych możliwe w całości do wykorzystywania przez przedsiębiorstwo w jego bieżącej działalności ${ }^{8}$, co wyraźnie

6 D. Lessard, D.J. Teece, S. Leih, The dynamic capabilities of meta-multinationals, „Global Strategy Journal" 2016, vol. 6, s. 211-224.

7 D.J. Teece, Dynamic capabilities: Routines versus entrepreneurial action, „Journal of Management Studies" 2012, vol. 49(8), s. 1395-1401.

8 M. Bratnicki, Kompetencje przedsiębiorstwa. Od określania kompetencji do zbudowania strategii, Wydawnictwo Placet, Warszawa 2000; Z. Patora-Wysocka, Rutyny organizacyjne w zarzq̨dzaniu z perspektywy procesualnej, Wydawnictwo Naukowe PWN, Warszawa 2019. 
wskazuje, iż zdolności organizacyjne są ściśle powiązane z problemami rutyn organizacyjnych i mają zasadniczy wpływ na ich zmiany. Rutyny pojawiają się na styku trwania i transformacji procesów uczenia się przedsiębiorstwa, jako powtarzalne wzorce współzależnych działań i elementy cząstkowych zdolności organizacyjnych ${ }^{9}$. Zwraca się także uwagę na ich dwoistość, która rozpatrywana jest z perspektywy gry między performatywnymi a ostensywnymi aspektami rutyn. Rutyny organizacyjne są odnoszone także do pojęcia praktyki jako zachowań (rutyn), które składają się z kilku elementów/działań połączonych ze sobą: formą aktywności fizycznej, formą aktywności umysłowej, „rzeczami” i ich wykorzystaniem, know-how, emocjami i wiedzą specjalistyczną ${ }^{10}$. Praktyki operacyjne mylone są często ze zdolnościami operacyjnymi ze względu na ich bliskie powiązania w działaniu rutyn operacyjnych. Wielu autorów wyraża pogląd, iż praktyki odnoszą się na pewno do skumulowanego doświadczenia pracowników przedsiębiorstwa ${ }^{11}$. Oczywiście określone praktyki są ściśle powiązane z rutynami organizacyjnymi i wykorzystywane w zakresie zdolności organizacyjnych przedsiębiorstwa.

Współczesne przedsiębiorstwa, funkcjonując w dynamicznym otoczeniu, muszą budować właściwy poziom zdolności organizacyjnych z wykorzystywaniem zasobów i kompetencji jako kluczowych i pokrewnych kategorii opisujących zmienność procesów ich konfigurowania i tworzenia potencjału przedsiębiorstwa. Zasoby organizacyjne są konstruktem podobnym do zdolności organizacyjnych, który obejmuje materialne i niematerialne aktywa rozwijane przez przedsiębiorstwo oraz wykorzystywane w celu osiągnięcia pożądanych efektów ${ }^{12}$. Blisko powiązane z nimi są kompetencje, reprezentujące wiązkę zasobów specyficznych dla przedsiębiorstwa aktywów, które wbudowane są w zintegrowaną wiązkę jednostek i grup, umożliwiającą realizację różnorodnych działań, tj. rutyny i procesy organizacyjne. Kompetencje w tym ujęciu są rozumiane w sensie możliwości

9 A. Paramigiani, J. Howard-Grenville, Routines revisited: Exploring the capabilities and practice perspective, „Academy of Management Annals” 2011, vol. 5(1), s. 413-453; C. Salvato, C. Rerup, Beyond collective entities: multilevel research on organizational routines and capabilities, „Journal of Management” 2011, vol. 37(2), s. 468-490.

10 A. Reckwitz, Toward a theory of social practices. A development in culturalist theorizing, „European Journal of Social Theory" 2002, vol. 5(2), s. 243-263.

11 N.K. Hansen, R. Vogel, Organizational routines: a review and outlook on practice-based microfoundations, „Economics, Management \& Financial Markets” 2011, vol. 6(3), s. 86-111; $\mathrm{H}$. Kerzner, Project management. A systems approach to planning, scheduling and controlling, John Wiley \& Sons, Hoboken 2009.

12 D.J. Teece, Dynamic capabilities and the multinational enterprises, [w:] B.J. Christensen, C. Kowalczyk (red.), Globalization, Springer-Verlag, Berlin - Heidelberg 2017, s. 105-129. 
konfigurowania, integrowania i zarządzania dostępnymi zasobami lub specyficznymi dla przedsiębiorstwa aktywami ${ }^{13}$.

Zdolności organizacyjne $\left(Z_{\text {org }}\right)$ są kombinacją dwóch rodzajów zdolności: operacyjnych $(Z O)$ i dynamicznych $(Z D)$, które proponujemy określać przy użyciu zależności:

$$
\begin{gathered}
Z_{\text {org }}=f\{Z O ; Z D\}, \\
Z O=P_{o}+\Delta Z O,
\end{gathered}
$$

gdzie:

$P_{o}$ - przepustowość operacyjna, czyli trwale osiągnięta zdolność operacyjna, $\triangle Z O$ - przyrost zdolności operacyjnych możliwych do uzyskania przez rekonfigurację obecnych zasobów i kompetencji.

Natomiast:

$$
Z D=Z O+\triangle Z D
$$

gdzie:

$\Delta Z D$ - przyrost zdolności dynamicznych tkwiących w zasobach nowych i przyszłościowych;

$$
\Delta Z D=\Delta Z D_{w}+\Delta Z D_{p}
$$

gdzie:

$\triangle Z D_{w}$ - przyrost zdolności dynamicznych własnych, możliwych do uzyskania przez rekonfigurację nowych zasobów i kompetencji oraz ich wzrostu, $\triangle Z D_{p}$ - przyrost zdolności dynamicznych pozyskiwanych z otoczenia (kooperacja, koopetycja, alianse).

Ostatecznie $Z_{\text {org }}$ staje się wynikiem synergicznych procesów kombinacji $Z O$ i $Z D$, które powinny osiągnąć poziom wyższy niż prosta suma ich składowych.

Komplementarne składowe zdolności organizacyjnych można symbolicznie zapisać w odniesieniu do rodzajów tych zdolności i szczebli zarządzania przedsiębiorstwem (tabela 1). Z oczywistych powodów zdolności dynamiczne mają większe znaczenie na poziomie strategicznym i taktycznym zarządzania przedsiębiorstwem, a zdolności operacyjne na poziomie operacyjnym i taktycznym. Oba wymiary zdolności

13 E. Stańczyk-Hugiet, Zdolności dynamiczne - w poszukiwaniu Świętego Grala?, [w:] K. Krzakiewicz, S. Cyfert (red.), Strategiczny wymiar dynamicznych zdolności polskich przedsiębiorstw, Wydawnictwo Uniwersytetu Ekonomicznego w Poznaniu, Poznań 2017, s. 27-45. 
najbardziej przenikają się na poziomie taktycznym. W tych samych zakresach można również odnosić się do zasobów materialnych i niematerialnych przedsiębiorstwa, powiązanych ze zdolnościami operacyjnymi i zdolnościami dynamicznymi, jak również do systemu zarządzania. Pogodzenie, wydawałoby się sprzecznych wymagań i uwarunkowań zdolności operacyjnych i dynamicznych, może następować z harmonijnym wykorzystywaniem metod operacyjnego i strategicznego zarządzania.

Tabela 1. Obszary oddziaływania rodzajów zdolności organizacyjnych

\begin{tabular}{|l|r|}
\hline \multicolumn{1}{|c|}{ Poziom zarządzania } & \multicolumn{1}{|c|}{ Zdolności organizacyjne } \\
\hline Strategiczny & \\
\hline Taktyczny & \\
\hline Operacyjny
\end{tabular}

ZD - zdolności dynamiczne

ZO - zdolności operacyjne

Źródło: opracowanie własne.

W kontekście dynamizmu otoczenia przedsiębiorstwa niezbędne jest odnawianie i rekonfigurowanie swoich zasobów i kompetencji oraz zdolności organizacyjnych, umożliwiających adaptowanie się do zmian otoczenia. Transformowanie zdolności organizacyjnych, jak założono w rozdziale, będzie odnosić się do ujęcia procesowego, które ma poszerzyć potencjał poznawczy dociekań naukowych dla potrzeb zarządzania zdolnościami organizacyjnymi przedsiębiorstwa, szczególnie na bazie procesów organizacyjnych, w celu osiągania ich przyrostu oraz efektów synergicznych.

\section{Procesy ksztattowania zdolności organizacyjnych}

Zdolności organizacyjne przedsiębiorstwa, najogólniej rzecz ujmując, definiują pewien poziom możliwości danego przedsiębiorstwa w określonych warunkach i w określonym przedziale czasu (np. miesiąc, kwartał, rok). W krótszych odcinkach czasu mają one mniejszą dynamikę, lecz w dłuższych ulegają naturalnej zmianie lub mogą być w sposób świadomy kształtowane. W naszych rozważaniach będziemy je rozpatrywać na tle zbioru procesów, które tworzą związki merytoryczne, przyczynowo-skutkowe i uwarunkowania kształtowania zdolności organizacyjnych przedsiębiorstwa.

Architektura procesów obejmuje system procesów (rysunek 1) zaangażowanych w kształtowanie się zdolności organizacyjnych, między którymi powstaje wiele wzajemnych zależności, szczególnie na bazie osiowego procesu organizacyjnego w przedsiębiorstwie. Procesy organizacyjne ${ }^{14}$ są jednym z najważniejszych

14 E. Skrzypek, M. Hofman, Zarządzanie procesami w przedsiębiorstwie, Wolters Kluwer, Warszawa 2010. 
przejawów działalności przedsiębiorstwa - w ich ramach wydzielane są następujące procesy, mające określoną rolę, miejsce i obszar oddziaływania w przedsiębiorstwie: przygotowawcze, podstawowe, pomocnicze i zarządzania. Procesy organizacyjne są też w pewnym sensie „właścicielem” pozostałych procesów, odpowiedzialnym za cały ich system. Obejmują one pełną sekwencję pozostałych procesów na poziomie operacyjnym i strategicznym, co umożliwia, poprzez jego parametry, monitorowanie poszczególnych procesów i zmian w aspekcie kształtowania zdolności organizacyjnych. Takie podejście do zdolności organizacyjnych (operacyjnych i dynamicznych) powoduje przebudowę spojrzenia na bardziej dynamiczne i rozłożone w czasie kształtowanie ich poziomów wspartych na przebiegach procesów organizacyjnych. Stają się one swoistą platformą odniesienia dla dynamiki pozostałych procesów, takich jak uczenia się, rekonfiguracji zasobów i kompetencji oraz w konsekwencji niezbędnych procesów zmian technologicznych i organizacyjnych. Mechanizmy doskonalące procesy organizacyjne w wyniku procesowego kształtowania zdolności organizacyjnych stwarzają niezbędne zmiany w realizowaniu procesów organizacyjnych i tym samym umożliwiają rozwój przedsiębiorstwa.

Dynamika zasobów i kompetencji zależy przede wszystkim od procesów ich rekonfiguracji oraz procesów uczenia się i rutynizacji w trakcie realizacji procesów organizacyjnych w przedsiębiorstwie. Uwzględniając aktualnie dostępne zasoby i kompetencje przedsiębiorstwa, można je aktywnie rekonfigurować wraz z nową reorganizacją fragmentów procesów organizacyjnych jako sytuacji emergentnych i naturalnego korygowania i wykorzystywania zdolności do elastycznego adaptowania się do zmiennych warunków.

Istotą przygotowywania się przedsiębiorstw do globalizującej się gospodarki jest budowanie przewagi konkurencyjnej, którą można osiągnąć między innymi przez kształtowanie zdolności organizacyjnych jako regularnego odnawiania przedsiębiorstwa. Optymalizacja zdolności organizacyjnych ma być dopasowywaniem i rekonfigurowaniem zasobów i kompetencji w zakresie zdolności operacyjnych i dynamicznych w indywidualny sposób, czyli atrybutów określonego przedsiębiorstwa „tu i teraz”, w odniesieniu do jego aktualnych potrzeb i uwarunkowań rynkowych. Procesy rekonfiguracji istniejących zasobów i kompetencji obejmują generowanie nowych kombinacji lub dołączenie nowych zasobów i kompetencji, najczęściej z zakresu zdolności dynamicznych, w nowy sposób, na bazie zreorganizowanych procesów organizacyjnych przedsiębiorstwa. Jednoczesne modyfikowanie przenikających się zdolności operacyjnych i zdolności dynamicznych - niejako „dwóch stron tego samego medalu” - łączy te dwa wymiary zdolności organizacyjnych w przedsiębiorstwie.

W trakcie realizacji procesów organizacyjnych w przedsiębiorstwie przebiegają procesy uczenia się, dzięki którym następuje scalanie nowej wiedzy i nowego 
doświadczenia. Jednocześnie procesy uczenia się pozwalają na rozpoznawanie dysfunkcjonalnych działań i ich modyfikację. Tworzy to szansę na bardziej adaptacyjne kształtowanie zmian i zdolności organizacyjnych przedsiębiorstwa w ramach pojedynczej pętli uczenia się, w zakresie zdolności operacyjnych, oraz podwójnej pętli uczenia się, odnoszącej się bardziej do zdolności dynamicznych. Oczywiście odbywa się ono jednocześnie, tworząc warunki usprawniające bieżącą działalność i możliwości dla przyszłych okresów działalności przedsiębiorstwa. W odniesieniu do obu rodzajów zdolności organizacyjnych zastosowanie mają różne formuły uczenia się:

- dla zdolności operacyjnych - uczenie się w działaniu i rutynizacja doświadczeń; produkcyjne uczenie się ${ }^{15}$;

- dla zdolności dynamicznych - organizacyjne uczenie się ${ }^{16}$.

Procesy uczenia się w przedsiębiorstwie są nośnikami zmian zdolności operacyjnych w zakresie ewolucji rutyn operacyjnych, jak również rozwoju zdolności dynamicznych w zakresie poszukiwania nowych wzorców zachowań (rutyn dynamicznych). W tym podejściu ugruntowały się dwa wymiary rutyn organizacyjnych, tj. rutyny operacyjne i rutyny dynamiczne. Przez wielu autorów są one traktowane jako procesy ${ }^{17}$ podążające wraz z procesami organizacyjnymi i procesami uczenia się w przedsiębiorstwie. W naszych rozważaniach skłaniamy się również w kierunku procesualnego ich traktowania, co współbrzmi z proponowaną mapą procesów (rysunek 1) kształtowania zdolności organizacyjnych - szczególnie procesy uczenia się kształtują procesy rutyn organizacyjnych.

Osadzenie problemów zdolności operacyjnych i zdolności dynamicznych jako pewnej całości na bazie procesów organizacyjnych, rekonfiguracyjnych, uczenia się i rutynizacji pozwala na uwzględnienie ich zmienności w szerszym kontekście poznawczym. Kształtowanie zmian zdolności organizacyjnych przedsiębiorstwa w ujęciu procesowym wzmacnia potrzebę nowej optyki rozumienia powiązań elementów składających się na zdolności operacyjne i zdolności dynamiczne. W centrum podejścia procesowego jest postrzeganie zmian zdolności organizacyjnych przez pryzmat integrowania zasobów i kompetencji na tle poszczególnych procesów zawartych w mapie procesów, gdzie następuje przenikanie się odwzorowanych,

15 M. Brzeziński, Formuty produkcyjnego uczenia się w teorii i badaniach przemystowych, „Prace Naukowe. Organizacja i Zarządzanie”, Seria A „Monografie”, nr 6, Politechnika Lubelska, Lublin 1983; A. Zgrzywa-Ziemak, R. Kamiński, Rozwój zdolności uczenia się przedsiębiorstwa, Wydawnictwo Difin, Warszawa 2009.

16 E. Stańczyk-Hugiet, Strategiczny kontekst zarzq̨dzania wiedzq, Wydawnictwo Akademii Ekonomicznej, Wrocław 2007; A. Zgrzywa-Ziemak, R. Kamiński, Rozwój zdolności uczenia się...

17 M.S. Feldman, B.T. Petoland, Reconceptualizing organizational routines as source of flexibility and change, „Administrative Science Quarterly” 2003, vol. 48(1), s. 94-118; Z. Patora-Wysocka, Rutyny organizacyjne... 
rutynowych i przewidywalnych już procesów z udoskonalonymi i zreorganizowanymi w nowy sposób procesami. Mają temu służyć procesy zmian technologicznych i procesy zmian organizacyjnych.

Zmiany technologiczne obejmują innowacje produktowe i procesy technologiczne $^{18}$, każda innowacja „przestraja” procesy organizacyjne, a tym samym wymusza rekonfigurację zasobów i kompetencji, szczególnie w obszarze zdolności operacyjnych przedsiębiorstwa. Natomiast z procesem innowacyjnym połączone są zawsze zmiany organizacyjne ${ }^{19}$ następujące w dłuższych okresach i w odniesieniu do zmian w zdolnościach dynamicznych, co odbija się przede wszystkim na systemie zarządzania w wymiarze strukturalnym oraz metod zarządzania przedsiębiorstwem.

\section{Koncepcja modelu rozwoju zdolności organizacyjnych}

Zachowania strategiczne przedsiębiorstwa w dużym stopniu reagują na zmiany w charakterystyce otoczenia, co wypływa między innymi z dwukierunkowości tych relacji, stwarzając także możliwości kształtowania otoczenia i szeroko pojętych procesów gospodarczych. Z perspektywy ujęcia zasobowego i procesowego każde przedsiębiorstwo osadzone właśnie w tym kontekście stara się pobudzać i rozwijać zasoby materialne i niematerialne jako bazę zasobową i potencjał kompetencji możliwych do wykorzystywania bieżącego oraz przyszłościowego. Budowanie zdolności organizacyjnych w procesie ich zmian w czasie jest otwieraniem się na procesy rekonfiguracji, jak też na pozyskiwanie nowych możliwości rozwoju zdolności organizacyjnych. To, w jakim tempie te procesy mogą przebiegać, jest ważnym pytaniem, na które poszukujemy odpowiedzi.

Zmiany poziomu zdolności organizacyjnych w sposób naturalny pojawiają się na styku problemów operacyjnych i określonej transformacji opisanych wcześniej procesów (mapa procesów - rysunek 1) kształtowania tych zdolności. Ich rozwój może być wyrażony przez zespolenie tych składowych procesów przebiegających w czasie, gdzie procesy uczenia się nadają tempo skumulowane w postaci funkcji rozwoju zdolności organizacyjnych przedsiębiorstwa. Niezbędne stają się więc: budowanie ich na bazie aktualnych zdolności operacyjnych i powiększanie poprzez rekonfigurację zasobów i kompetencji oraz wyłaniające się nowe

18 M. Brzeziński, Wdrażanie innowacji technologicznych, Wydawnictwo Difin, Warszawa 2015.

19 T. Kraśnicka, Innowacje w zarządzaniu. Nowe ujęcie, Wydawnictwo C.H. Beck, Warszawa 2018. 
zdolności dynamiczne, uwzględniające prognozowane i strategiczne możliwości rozwoju przedsiębiorstwa. W pewnym sensie jest to „przeciąganie liny” pomiędzy odtwarzaniem operacyjnych i wyuczonych już sposobów działania, wykorzystujących zdolności operacyjne, a jednoczesnym uwzględnianiem nowych uwarunkowań i metod działania, wykorzystujących zdolności dynamiczne. Mechanizm ten ma zoptymalizować poziom zdolności organizacyjnych, będących czymś więcej niż odwzorowaniem zdolności operacyjnych powiększonych o nowe możliwości wynikające ze zdolności dynamicznych.

Zdolności organizacyjne to poziom potencjału przedsiębiorstwa w aktualnych warunkach i w określonym czasie bieżącym i perspektywie planistycznej oraz w zakresie kształtowania i wykorzystywania zróżnicowanych zasobów i kompetencji. Przedsiębiorstwa dzięki rozwojowi zdolności organizacyjnych i „rozpiętych” na nich zasobów i kompetencji mogą szybciej adaptować się do zmian otoczenia i wdrażania procesów odnowy organizacyjnej.

Narastanie zdolności organizacyjnych może teoretycznie przebiegać według czterech funkcji: liniowej, potęgowej, wykładniczej i logistycznej (rysunek 2a). Patrząc od strony teoretycznej na poszczególne funkcje, można zauważyć, iż mają one różne cechy charakterystyczne, które mniej lub bardziej predestynują je do przyjęcia ich jako modelu rozwoju $Z_{\text {org }} \mathrm{w}$ przedsiębiorstwie. I tak: funkcja liniowa przebiega w takim samym tempie w fazie początkowej i końcowej, co może tworzyć problemy, szczególnie w fazie początkowej, z uwagi na rozpoczynanie procesu uczenia się. Funkcja potęgowa ma fazę startu z gwałtownym przyspieszeniem narastania poziomu zdolności, co w odniesieniu do zdolności operacyjnych i ich jednopętlowego uczenia się wydaje się mało przystające do realiów w tym zakresie. Funkcję potęgową zaproponowali Rockard i Dutt jako trajektorię procesu rozwoju zdolności przedsiębiorstwa o różnym tempie narastania między istniejącymi i potencjalnymi zdolnościami ${ }^{20}$. Funkcja wykładnicza przeciwnie - przyspiesza gwałtownie w końcowej fazie dochodzenia do zdolności docelowych przedsiębiorstwa. Funkcja logistyczna łączy w sobie pozytywne cechy tych poprzednich, nadając łagodny przebieg na początku, przyspieszenie w fazie środkowej i również łagodne przejście przez ostatnią fazę osiągania zdolności docelowych. Ostatnia faza, pomimo łagodnego charakteru, bazuje już na co najmniej osiemdziesięcioprocentowym poziomie osiąganych zdolności. Harmonijne połączenie trzech faz tej funkcji umożliwia najlepsze odwzorowywanie procesów przebiegających

20 S.F. Rockart, N. Dutt, The rate and potential of capability development trajectories, „Strategic Management Journal” 2015, no. 36, s. 53-75; A. Wójcik-Karpacz, Mechanizmy i ścieżki rozwoju zdolności dynamicznych, [w:] K. Krzakiewicz, S. Cyfert (red.), Strategiczny wymiar dynamicznych zdolności polskich przedsiębiorstw, Wydawnictwo Uniwersytetu Ekonomicznego w Poznaniu, Poznań 2017, s. 343-366. 
w trakcie rozwoju zdolności organizacyjnych. Również fakt wykorzystywania tej funkcji w różnych dziedzinach nauki do opisu procesów rozwojowych oraz rozwoju produkcji ${ }^{21}$ ostatecznie wskazał na wybór spośród czterech funkcji właśnie funkcji logistycznej jako modelu rozwoju zdolności organizacyjnych przedsiębiorstwa (rysunek 2b).
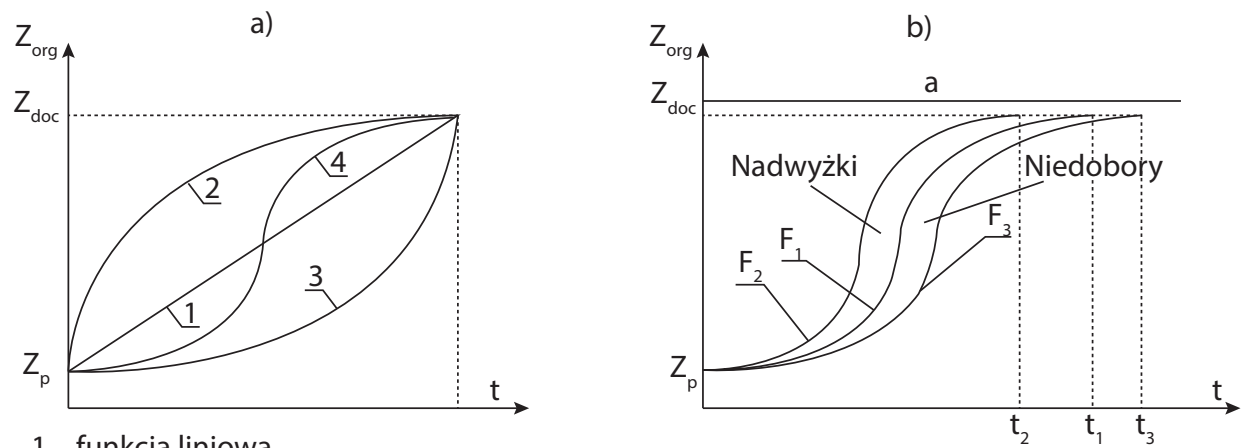

1 - funkcja liniowa

2 - funkcja potęgowa

3 - funkcja wykładnicza

4 - funkcja logistyczna

$\mathrm{Z}_{\text {org }}$ - zdolności organizacyjne

$\mathrm{Z}_{\mathrm{p}}$ - zdolności początkowe

(przepustowość operacyjna)

$Z_{\text {doc }}$ - docelowy poziom $Z_{\text {org }}$

a - asymptota pozioma funkcji logistycznej

$F_{1}$ - funkcja o płynnym tempie rozwoju $Z_{\text {org }}$

$\mathrm{F}_{2}$ - funkcja o przyspieszonym

tempie rozwoju $Z_{\text {org }}$

$F_{3}$ - funkcja o spowolnionym

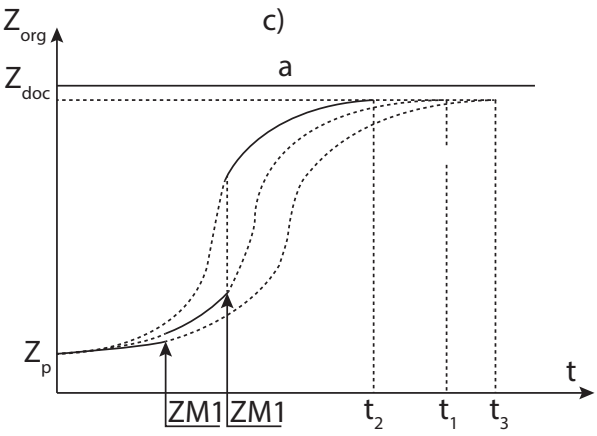

tempie rozwoju $Z_{\text {org }}$

ZM1-ZM2 - zmiany skokowe

$\mathrm{t}$ - czas

Rysunek 2. Trajektorie rozwoju zdolności organizacyjnych $\left(Z_{\text {org }}\right)$ : a) teoretyczne warianty rozwoju $Z_{\text {org }}$, b) pęk funkcji rozwoju $Z_{\text {org }} z$ ciągłymi procesami zmian, c) funkcja rozwoju $Z_{\text {org }}$ ze skokowymi procesami zmian

Źródło: opracowanie własne.

Model funkcji rozwoju zdolności organizacyjnych proponujemy rozpatrywać w dwóch odmianach, tj. z ciągłymi procesami zmian (rysunek 2 b) oraz skokowymi procesami zmian (rysunek 2 c). Model funkcji rozwoju $Z_{\text {org }}$ według funkcji logistycznej przybiera postać:

21 M. Brzeziński, Podstawy metodyczne projektowania rozruchu nowej produkcji, Wydawnictwo Naukowe PWN, Warszawa 1996. 


$$
Z_{\text {org }}=\frac{a}{1+b \cdot e^{-c t}}
$$

gdzie:

$a$ - asymptota pozioma funkcji logistycznej,

$b, c$ - parametry charakteryzujące przebieg funkcji,

$e$ - stała matematyczna 2,718 ,

$t$ - czas.

Narastanie $Z_{\text {org }}$ rozpoczyna się od $Z_{p}$ jako zdolności początkowej (przepustowości operacyjnej) znanej przedsiębiorstwu z ubiegłego roku, a następnie w kolejnych odcinkach czasu (np. miesiąc) krzywa logistyczna dąży do normatywnie przyjętej, docelowej wielkości $Z_{d o c}$. Ponieważ dla równania funkcji logistycznej osiąganie $a$ zachodzi dla $t$ dążącego do nieskończoności, niezbędne jest przyjęcie założenia, że rzędna odpowiadająca tej asymptocie jest nieco większa niż docelowa wielkość $Z_{d o c}$, czyli:

$$
a=Z_{d o c} \cdot(1+\gamma)
$$

gdzie:

$Z_{d o c}$ - docelowa, projektowana wielkość zdolności organizacyjnych, na przykład mierzona zdolnością produkcji w sztukach lub w ogólnym ujęciu w procentach dla ustabilizowanego osiągania $Z_{\text {org }}$;

$\gamma$ - dokładność osiągania asymptoty $a$; współczynnik ten można przyjmować w zależności od tego, jak dokładny wynik obliczeń chcemy uzyskać; zadowalające wyniki można otrzymać, przyjmując $\gamma$ od 0,01 do 0,02 .

Parametr $b$ charakteryzujący krzywą logistyczną wyznaczamy dla $t=0$, $Z_{\text {org }}=Z_{p}$ oraz:

$$
\begin{gathered}
Z_{\text {org }}=\frac{a}{1+b}, \\
b=\frac{Z_{d o c}(1+\gamma)}{Z_{p}}-1 .
\end{gathered}
$$

Przy użyciu parametrów $a$ i $b$ funkcji logistycznej możemy wyznaczyć pęk krzywych (rysunek 2 b), wśród których będą funkcje $F_{1}, F_{2}, F_{3}$, odnoszące się do przyjętego tempa osiągania $Z_{\text {org }}$ : płynnego osiągania $Z_{\text {doc }}$ w czasie $t_{1}\left(F_{1}\right)$, przyspieszonego osiągania $Z_{\text {doc }}$ w czasie $t_{2}\left(F_{2}\right)$, spowolnionego osiągania $Z_{\text {doc }}$ w czasie $t_{3}\left(F_{3}\right)$. 
Wtedy poszukujemy parametru $c$ dla:

$$
Z_{d o c}=\frac{a}{1+b e^{-c t_{i}}}
$$

po przekształceniu otrzymujemy:

$$
c=-\frac{\ln \frac{\gamma}{b}}{t_{i}},
$$

gdzie:

$t_{i}$ - czas trwania osiągania $Z_{\text {doc }} i$-tego wariantu rozwoju $Z_{\text {org }}$.

Pęk krzywych składa się z trzech funkcji $F_{1}, F_{2}, F_{3}, z$ których $F_{1}$ jest pewnego rodzaju „wzorcem” harmonijnego przebiegu narastania $Z_{\text {org }}$, natomiast $F_{2} z$ założenia tworzy nadwyżki względem wzorcowej $F_{1}$, a $F_{3}$ tworzy niedobory względem wzorcowej $F_{1}$. Mając określone parametry krzywej logistycznej $a, b, c$, można obliczać wielkości narastania $Z_{\text {doc }}$ dla $F_{1}, F_{2}, F_{3}$ w dowolnym momencie czasów $t_{1}$, $t_{2}, t_{3}$. Odstępstwa od $F_{1} \mathrm{w}$ praktyce będą się oczywiście zdarzać, więc trzeba skorygować płynny model według $F_{1}$ poprzez uruchomienie zmian skokowych (rysunek 2c), w celu wyregulowania lub przyspieszenia osiągania $Z_{d o c}$. Zmiany ZM1 i ZM2 w praktyce mogą uruchamiać mechanizmy przystosowawcze, które skorygują i zoptymalizują tempo rozwoju $Z_{\text {org }}$ w przedsiębiorstwie.

W naszych założeniach nie koncentrujemy się na wcześniejszym przygotowaniu nadmiarów $Z_{\text {org }}$ które mogą być lepiej lub gorzej wykorzystywane (np. marnotrawione), lecz na płynnym osiąganiu $Z_{\text {doc }}$ poprzez dobieranie właściwych parametrów $b$ i $c$ funkcji logistycznej $F_{1}$. Dobieranie właściwego tempa i trendu narastania $Z_{\text {org }}$ rozpoczyna się od znanego z poprzedniego okresu, na przykład roku, i osiągniętego już poziomu początkowego $Z_{p}$ jako operacyjnej przepustowości przedsiębiorstwa przebiegającej w czasie realizacji osiowego procesu organizacyjnego. W każdym przedsiębiorstwie niezbędne będzie przeprowadzenie badań empirycznych z poprzednich lat dla ustalenia niezbędnych zakresów parametrów $b$ i $c$, które - w zależności od ich wielkości - dobierane będą w planowaniu i projektowaniu przebiegów $Z_{\text {org }}$ konkretnego przedsiębiorstwa. Diagnozowanie danych $\mathrm{z}$ procesów rozwojowych z poprzednich lat umożliwi utworzenie dla przedsiębiorstw własnych zbiorów normatywnych wielkości $b$ i $c$ w zakresie przyjętych kryteriów, przede wszystkim odnoszących się do procesów uczenia się oraz na przykład poziomu doświadczenia pracowników fizycznych (ważnego dla 
zdolności operacyjnych), poziomu intelektualnego kadry kierowniczej (ważnego dla zdolności dynamicznych), poziomu innowacyjności (ważnego dla wprowadzania zmian skokowych) itp.

Dla $F_{1}$ dobrane parametry $b$ i $c$ mają zapewnić ciągłe i stabilne narastanie i rozwój $Z_{\text {org }}$ które w przypadku korekcyjnych rekonfiguracji zasobów i kompetencji „nie burzą” tempa narastania tych zdolności organizacyjnych. W przypadku na przykład losowego obniżania się $Z_{\text {org }}$ i tym samym tworzenia się niedoborów mogą pojawiać się potrzeby wprowadzania zmian skokowych:

- ZM1 - dla ratowania tempa zbliżonego lub identycznego jak według funkcji $F_{1}$;

- ZM2 - niezbędnych do przyspieszania tempa narastania według funkcji $F_{2}$; decyzje kierownictwa przedsiębiorstwa najczęściej wynikają z powodów strategicznych, a więc poszukiwania przyrostów zdolności dynamicznych.

W modelu stosującym skokowy przebieg zmian powstaje składana funkcja narastania $Z_{\text {org }}$, którą graficznie prezentuje rysunek 2 c. Stwarza to potrzebę obliczania, zgodnie z podanymi powyżej wzorami, poszczególnych zakresów i fragmentów takiej „poszarpanej” krzywej $Z_{d o c}$ w odniesieniu do funkcji $F_{1}, F_{2}, F_{3}$ oraz ich fragmentów po uwzględnieniu ZM1 i ZM2.

Elastyczne poruszanie się w polu zawartym pomiędzy funkcjami $F_{1}$ i $F_{2}$ umożliwia zaadaptowanie poszczególnych zmian ZM1 i ZM2 (i następnych) do konkretnych warunków i wariantów określonego podejścia planistyczno-projektowego. Powyższa procedura stwarza także możliwości włączania, w poszczególnych przekrojach czasowych, adekwatnych poziomów $Z_{\text {org }}$ i eliminowania ewentualnych zaburzeń w tempie ich narastania w przedsiębiorstwie. Może być także wkomponowana w procesy modyfikowania harmonogramów rozwojowych i systemów zarządzania operacyjnego i strategicznego, co rzutować będzie na oblicze organizacyjno-ekonomiczne przedsiębiorstwa.

\section{Podsumowanie}

Podejście procesualne w naukach o zarządzaniu wskazuje na znaczenie procesowych połączeń w realizacji przedsięwzięć rozwojowych przedsiębiorstwa. Mapa procesów (rysunek 1) stanowi więc merytoryczny budulec w perspektywie poznawczej kształtowania zdolności organizacyjnych przedsiębiorstwa, które są trudne do jednoznacznego opisu bez uwzględniania ich przebiegów w czasie. Procesowy obraz pokazuje tutaj współzależności zachodzących w nim zjawisk budowania i rekonfigurowania powiązań, zasobów i kompetencji w czasie przebiegu kluczowych procesów: organizacyjnych, uczenia się i rutynizacji działań na rzecz rozwoju zdolności organizacyjnych przedsiębiorstwa. Zaproponowany model ich rozwoju w postaci 
funkcji logistycznej (rysunek 2) stwarza warunki do projektowania narastania poziomu zdolności organizacyjnych przedsiębiorstwa.

Teoretyczny charakter rozważań przedstawionych w niniejszym rozdziale powinien być uzupełniony o badania empiryczne dynamiki $Z_{\text {org }}$ w zakresie:

- podłużnym (procesowym); w procesie osiągania $Z_{d o c}$, z odniesieniem do kluczowych procesów organizacyjnych, uczenia się i rutynizacji;

- poprzecznym (przekrojowym); w wybranych momentach procesu osiągania $Z_{d o c}$, w odniesieniu do zmian technologicznych i organizacyjnych.

W pierwszym przypadku wyniki badań pozwolą na doświadczalne określenie normatywnych zakresów współczynników tempa rozwoju zdolności organizacyjnych ( $b$ i $c$ ), z rozróżnieniem wpływu ich kluczowych procesów w danym przedsiębiorstwie, a w drugim przypadku na uzyskanie danych i informacji na temat zasobów i kompetencji, których zmiany wypływają z potrzeby wdrażania zmian technologicznych i organizacyjnych. Powiązanie wyników z obu zakresów diagnostycznych może określić skutki zachodzących zmian i ocenić ewolucyjny czy też skokowy ich charakter w przedsiębiorstwie. Ewentualne badania w wielu przedsiębiorstwach mogłyby ujawnić bardziej uogólnione zjawiska kształtowania dynamiki $Z_{\text {org }}$ z zastrzeżeniem dużej ostrożności wnioskowania z uwagi na trudną porównywalność indywidualnych i unikatowych $Z_{\text {org }} \mathrm{W}$ różniących się przedsiębiorstwach określonej branży.

\section{Bibliografia}

Barney J.B., Clark D.N., Resource-based theory. Creating and sustaining competitive advantage, Oxford University Press, New York 2007.

Bratnicki M., Kompetencje przedsiębiorstwa. Od określania kompetencji do zbudowania strategii, Wydawnictwo Placet, Warszawa 2000.

Brzeziński M., Formuły produkcyjnego uczenia się w teorii i badaniach przemysłowych, „Prace Naukowe. Organizacja i Zarządzanie”, Seria A „Monografie”, nr 6, Politechnika Lubelska, Lublin 1983.

Brzeziński M., Podstawy metodyczne projektowania rozruchu nowej produkcji, Wydawnictwo Naukowe PWN, Warszawa 1996.

Brzeziński M., Wdrażanie innowacji technologicznych, Wydawnictwo Difin, Warszawa 2015.

Eisenhardt K.M., Martin J.A., Dynamic capabilities: What are they?, „Strategic Management Journal" 2000, vol. 21, s. 1105-1121.

Feldman M.S., Petoland B.T., Reconceptualizing organizational routines as source of flexibility and change, „Administrative Science Quarterly” 2003, vol. 48(1), s. 94-118.

Hansen N.K., Vogel R., Organizational routines: a review and outlook on practice-based microfoundations, „Economics, Management \& Financial Markets” 2011, vol. 6(3), s. 86-111.

Kerzner H., Project management. A systems approach to planning, scheduling and controlling, John Wiley \& Sons, Hoboken 2009.

Kraśnicka T., Innowacje w zarzq̨dzaniu. Nowe ujęcie, Wydawnictwo C.H. Beck, Warszawa 2018. 
Krupski R., Rozwój szkoły zasobowej zarzq̨dzania strategicznego, Wydawnictwo Wyższej Szkoły Zarządzania i Przedsiębiorczości, Watbrzych 2011.

Krzakiewicz K., Cyfert S., The Strategic Dimension of the Dynamic Capabilities Enterprises, „Management" 2014, vol. 18, no. 2, s. 7-18.

Krzakiewicz K., Cyfert S. (red.), Strategiczny wymiar dynamicznych zdolności polskich przedsiębiorstw, Wydawnictwo Uniwersytetu Ekonomicznego w Poznaniu, Poznań 2017.

Lessard D., Teece D.J., Leih S., The dynamic capabilities of meta-multinationals, „Global Strategy Journal" 2016, vol. 6, s. 211-224.

Paramigiani A., Howard-Grenville J., Routines revisited: Exploring the capabilities and practice perspective, „Academy of Management Annals” 2011, vol. 5(1), s. 413-453.

Patora-Wysocka Z., Rutyny organizacyjne w zarządzaniu z perspektywy procesualnej, Wydawnictwo Naukowe PWN, Warszawa 2019.

Peteraf M.A., Barney J.B., Unraveling the resource-based tangle, „Managerial and Decision Economics" 2003, vol. 24(4), s. 309-323.

Reckwitz A., Toward a theory of social practices. A development in culturalist theorizing, „European Journal of Social Theory" 2002, vol. 5(2), s. 243-263.

Rockart S.F., Dutt N., The rate and potential of capability development trajectories, „Strategic Management Journal" 2015, no. 36, s. 53-75.

Salvato C., Rerup C., Beyond collective entities: multilevel research on organizational routines and capabilities, „Journal of Management” 2011, vol. 37(2), s. 468-490.

Skrzypek E., Hofman M., Zarządzanie procesami w przedsiębiorstwie, Wolters Kluwer, Warszawa 2010.

Sopińska A., Potencjał zasobowy polskich przedsiębiorstw, [w:] M. Romanowska, W. Mierzejewska (red.), Przedsiębiorstwo odporne na kryzys, Wolters Kluwer, Warszawa 2016.

Stańczyk-Hugiet E., Strategiczny kontekst zarzq̨dzania wiedzq, Wydawnictwo Akademii Ekonomicznej, Wrocław 2007.

Stańczyk-Hugiet E., Zdolności dynamiczne - w poszukiwaniu Świętego Grala?, [w:] K. Krzakiewicz, S. Cyfert (red.), Strategiczny wymiar dynamicznych zdolności polskich przedsiębiorstw, Wydawnictwo Uniwersytetu Ekonomicznego w Poznaniu, Poznań 2017, s. 27-45.

Suszyński C., Szkoła zasobowa wobec przeobrażeń otoczenia współczesnych przedsiębiorstw, Wydawnictwo Wyższej Szkoły Zarządzania i Przedsiębiorczości, Wałbrzych 2011.

Teece D.J., Dynamic capabilities: Routines versus entrepreneurial action, „, Journal of Management Studies" 2012, vol. 49(8), s. 1395-1401.

Teece D.J., Dynamic capabilities and the multinational enterprises, [w:] B.J. Christensen, C. Kowalczyk (red.), Globalization, Springer-Verlag, Berlin - Heidelberg 2017, s. 105-129.

Wójcik-Karpacz A., Mechanizmy i ścieżki rozwoju zdolności dynamicznych, [w:] K. Krzakiewicz, S. Cyfert (red.), Strategiczny wymiar dynamicznych zdolności polskich przedsiębiorstw, Wydawnictwo Uniwersytetu Ekonomicznego w Poznaniu, Poznań 2017, s. 343-366.

Wójcik-Karpacz A., Zdolności dynamiczne versus zdolności operacyjne, „Organizacja i Kierowanie" 2017, nr 1, s. 51-70.

Wójcik-Karpacz A., Zdolności organizacyjne w kontekście wyników przedsiębiorstwa. Aspekty teoretyczne i wyniki badań empirycznych, Wydawnictwo Naukowe PWN, Warszawa 2019.

Wu S.J., Melnyk S.A., Flynn B.B., Operational capabilities: The secret ingredient, „Decision Sciences" 2010, vol. 41(4), s. 72-754.

Zakrzewska-Bielawska A., Strategie rozwoju przedsiębiorstw. Nowe spojrzenie, Polskie Wydawnictwo Ekonomiczne, Warszawa 2018.

Zgrzywa-Ziemak A., Kamiński R., Rozwój zdolności uczenia się przedsiębiorstwa, Wydawnictwo Difin, Warszawa 2009. 


\section{Streszczenie}

Zdolności organizacyjne przedsiębiorstwa w podejściu zasobowym odgrywają coraz ważniejszą rolę zarówno w wymiarze operacyjnym, jak i strategicznym. Zaproponowana mapa procesów kształtujących te zdolności stanowi merytoryczną bazę współzależności zasobów i kompetencji oraz wyróżnionych tam procesów: rekonfiguracji, organizacyjnych, uczenia się, rutynizacji oraz zmian technologicznych i organizacyjnych. W trakcie ich realizacji następuje proces narastania i rozwoju poziomu zdolności organizacyjnych, na którego model wybrano funkcję logistyczną w dwóch odmianach: z ciągłym i skokowym procesem zmian. Zaprezentowano także procedurę obliczania parametrów funkcji narastania zdolności organizacyjnych.

Słowa kluczowe: zdolności organizacyjne, mapa procesów, model rozwoju zdolności organizacyjnych przedsiębiorstwa

Organizational skills of the enterprise - a process approach

\section{Abstract}

The company's organizational skills in resource-based theory play an increasingly important role both in the operational and strategic dimensions therein. The proposed map of processes shaping these abilities constitutes a substantive basis for the interdependence of resources and competences and the processes identified therein: reconfiguration, organizational, learning, routinization, as well as technological and organizational changes. During their implementation, the company's organizational skills are being developed and upgraded; this process can be presented by means of one of the two logistic functions: with a continuous or step change process. The procedure of calculating the parameters of the function of increasing organizational skills has also been presented.

Keywords: organizational skills, process map, organizational development model of the company 